\title{
15
}

\section{Shades of Green: Using SWMM LID Controls to Simulate Green Infrastructure}

\section{Matthew McCutcheon and Derek Wride}

Green infrastructure is increasingly being considered for application in urban storm water management designs. Many municipalities, regulatory agencies and advocacy groups promote the use of low impact development (LID) to reduce runoff and increase infiltration. To show LID benefits, engineers must quantify the advantages of green versus traditional grey infrastructure. The United States Environmental Protection Agency (USEPA) updated its Storm Water Management Model (SWMM) with explicit LID controls in 2009 to assist engineers in quantifying green infrastructure benefits (Gironas et al., 2009). SWMM can now simulate five LID devices: bioretention cells; infiltration trenches; porous pavements; rain barrels; and vegetated swales.

Limited documentation is available regarding modeling techniques using the LID controls; the SWMM5 Applications Manual discusses modeling LID using SWMM features available before the LID controls were added. This study presents an initial evaluation of green infrastructure modeling using SWMM LID controls in SWMM version 5.0.022, released April 2011. The bioretention cell was selected for this evaluation because it most accurately represents a rain garden. Regardless of the LID control selected for simulation, the basic parameters for soil properties, storage volumes, surface characteristics, and underdrains are essentially the same among green infrastructure devices.

A demonstration study from Madison, Wisconsin (Selbig and Balster, 2010) was used for comparison. In that study, the United States Geological

McCutcheon, M. and D. Wride. 2013. "Shades of Green: Using SWMM LID Controls to Simulate Green Infrastructure." Journal of Water Management Modeling R246-15. doi: 10.14796/JWMM.R246-15.

(C) CHI 2013 www.chijournal.org ISSN: 2292-6062 (Formerly in Pragmatic Modeling of Urban Water Systems. ISBN: 978-0-9808853-8-5) 
Survey (USGS) and the University of Wisconsin measured and evaluated performance of turfgrass and prairie-vegetated rain gardens in clay and sand soils. SWMM LID controls were used to replicate the Madison study. The model yields good agreement with the measured data.

While this study only incorporated one SWMM LID control, its results are significant. This effort shows that the bioretention cell LID control reasonably reproduces published results for both long term and single event simulations, and that with acceptable values for green infrastructure it is possible to calibrate, validate and evaluate green infrastructure using SWMM LID controls.

\subsection{Methodology}

\subsubsection{Field Data}

Field data were obtained from two sites in Madison, Wisconsin previously reported on by Selbig and Balster (2010). Results from that study are cited throughout this paper. The sites were selected to represent different soil conditions. Rain gardens were constructed with equipment typically found among a homeowner's garden tools, or available for rent to a homeowner at a home improvement store (e.g. skid loader, rototiller). A level uniform surface was constructed at the base of each rain garden. To promote vegetation growth, 4 in. to 6 in. $(10.2 \mathrm{~cm}$ to $15.3 \mathrm{~cm})$ screened compost was mixed into the bottom of each rain garden using a rototiller. Turf rain gardens were seeded with a mix of Kentucky bluegrass, red fescue and perennial rye grass. Prairie rain gardens were planted with a diverse selection of species. Each prairie rain garden was planted with dormant plugs spaced $1 \mathrm{ft}(30.5 \mathrm{~cm})$ apart. Rain garden construction was completed in 2003. By spring 2004, the gardens were well established and data logging began.

Each LID device captured runoff from rooftops. The ratio of tributary area to LID area was nearly 5:1 for all LID catchments. Figure 15.1 opposite shows the setup of the clay rain gardens. The prairie-clay rain garden is in the foreground and the turf-clay rain garden in the background with the rain gauge in the middle of the garden. H-flumes were used to measure influent and effluent. Soil moisture probes were inserted in each garden.

Figure 15.2 opposite shows the setup of the turf-sand rain garden. A buffer tank and tipping bucket were used to measure influent. Soil moisture probes were inserted in the bottom of each garden. An H-flume was chosen for measuring effluent from the turf-sand rain garden. The prairie-sand rain garden (not shown) was constructed in a similar setting on the opposite side of the building visible in Figure 15.2. 


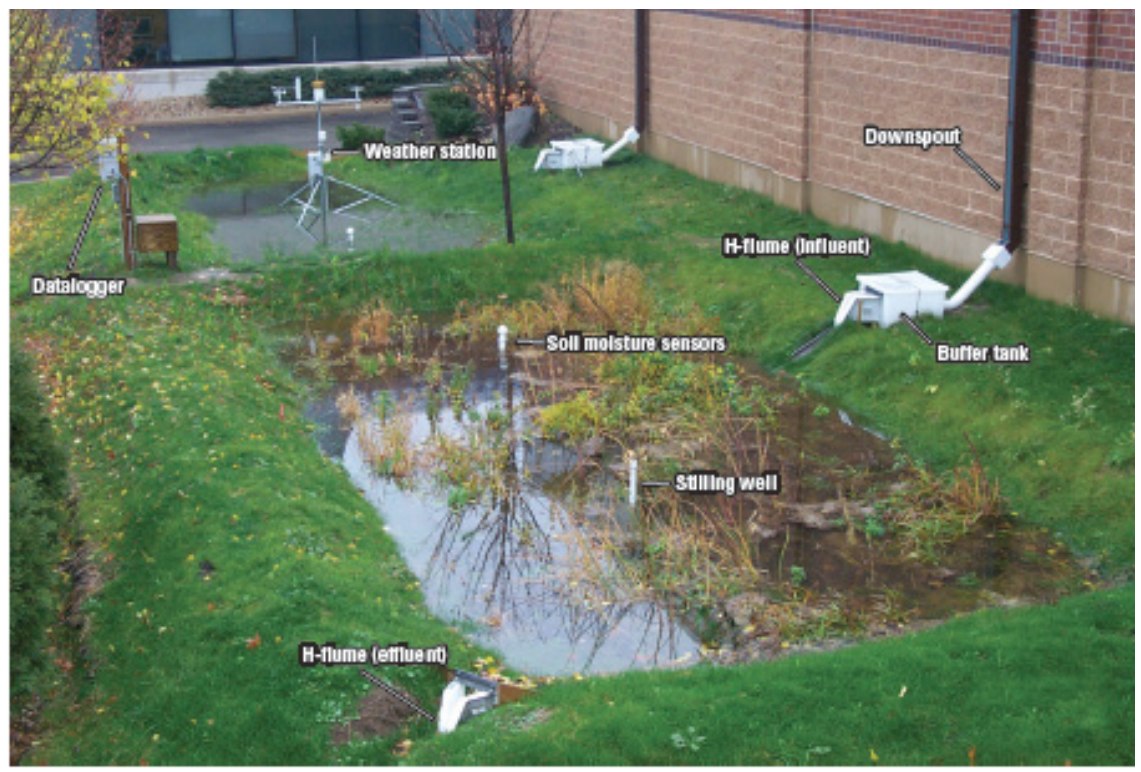

Figure 15.1 Field setup of clay rain gardens (courtesy of Selbig and Balster, 2010).

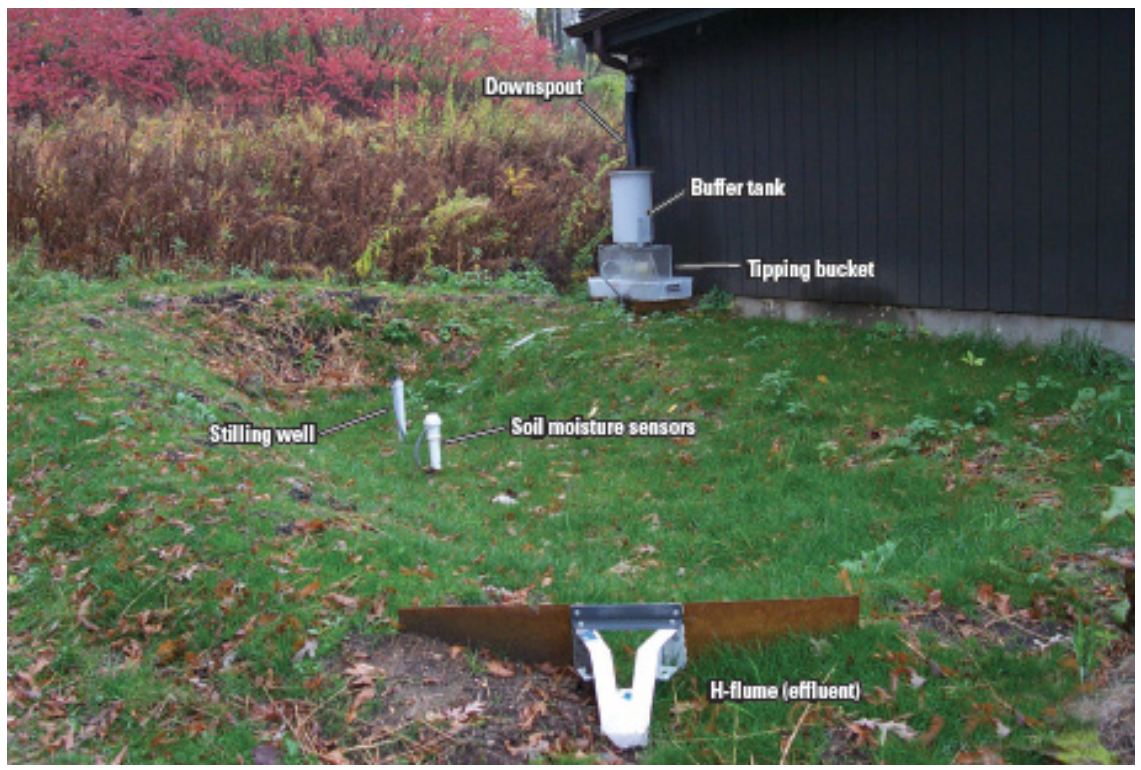

Figure 15.2 Field setup of turf-sand rain garden (courtesy of Selbig and Balster, 2010). 
During the 4 y study, both rain gardens in sand and the prairie rain garden in clay infiltrated all precipitation and runoff from the rooftops. The turfgrass rain garden infiltrated $96 \%$ of rainfall and rooftop runoff, overflowing during only 6 events.

\subsubsection{LID Modeling Techniques}

LID practices are designed to capture surface runoff, providing detention, infiltration, evapotranspiration, or some combination of the three. SWMM LID features are attributes of individual subcatchments. Multiple LID controls can be assigned to each subcatchment. SWMM allows the user to choose among two approaches for placing LID controls:

Create a new subcatchment dedicated exclusively to a single LID control; or

- Place one or more LID controls within an existing subcatchment, displacing an equal amount of non-LID area from the subcatchment

Using the first approach, only one LID control is represented by a single subcatchment. Figure 15.3 opposite shows the layout for using the first approach using the SWMM LID controls. In this configuration, LID controls act in series when one LID subcatchment is routed to another. Under this configuration, LID controls cannot act in parallel because only one outlet can be specified for each subcatchment. If this approach is being used for an existing model (retrofit situation or similar) after the new LID subcatchment is created, the original subcatchment's area, imperviousness, and width parameters must be adjusted to compensate for the area occupied by the LID. If this approach is used in a new model, the area of the LID subcatchment should not be double counted in the non-LID subcatchment area.

Figure 15.4 opposite shows the conceptual layout using the second approach. Using this approach, multiple LID controls can be placed in a single subcatchment. In this configuration, the controls can only act in parallel. It is not possible to route flow from one LID control to another when multiple LID controls are specified for a single subcatchment. When the controls act in parallel, each accepts runoff from a different portion of the subcatchment. However, it is not possible to specify which portion of the runoff flows to a specific LID control, other than by specifying the type of tributary area (pervious or impervious). (Note that as of 2012, SWMM5 does not allow runoff from pervious areas to LIDs.) The subcatchment's imperviousness and width parameters must be adjusted to reflect the inclusion of the LID control.

The properties of the LID controls are specified on a per-unit-area basis, allowing the same LID control to be placed in several subcatchments with different areal coverage. 


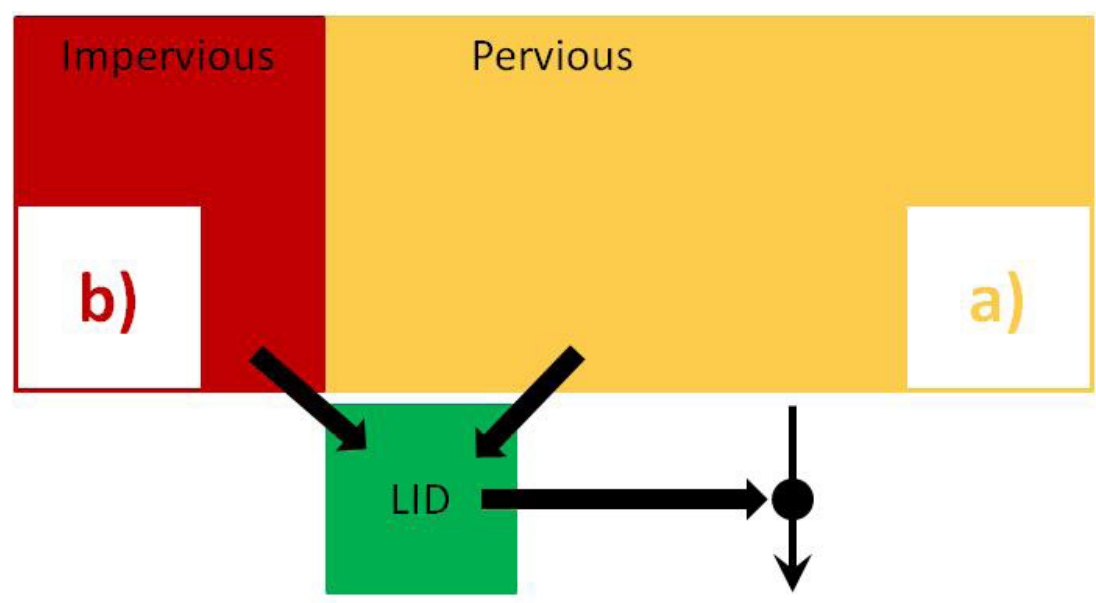

Figure 15.3 LID modeling approach 1 schematic.

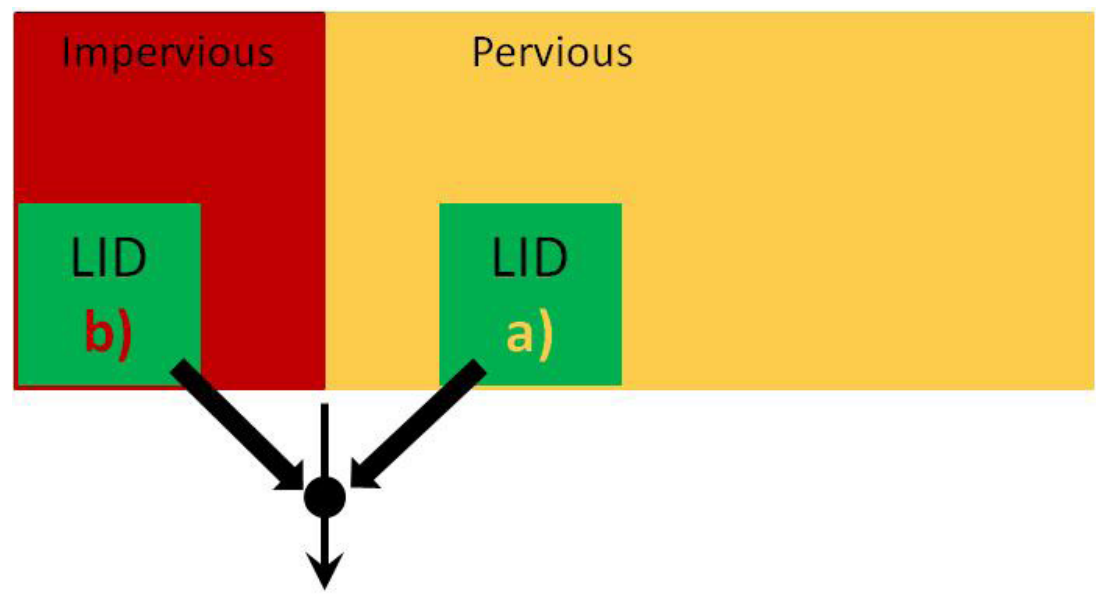

Figure 15.4 LID modeling approach 2 schematic.

\subsubsection{Simulation Procedure}

The first modeling technique was used for this study. The turf-clay, turf-sand, prairie-clay, and prairie-sand rain gardens were each modeled as their own catchment fully occupied by a bioretention cell LID control. Due to the highly localized nature of green infrastructure, sizing guidelines are site dependent and no standard green infrastructure sizing ratio of drainage area to LID area has been recognized (Heitz et al., 2000; Akan, 2002; Mungasavalli and 
Viraraghavan, 2006). An assumption of the tributary area to LID area ratio was not required for this study since the field work already performed had established a 5:1 ratio.

SWMM was configured to represent the Madison rain garden study. Rooftops were modeled as catchments tributary to the bioretention cell LID control catchments. The simulation was run for 2004-2007. The total number of LID overflows as well as the total volume of overflow was used for comparison. The model characteristics include:

four rooftop catchments;

four LID catchments;

turfgrass rain garden in clay soil;

turfgrass rain garden in sand soil;

prairie vegetation rain garden in clay soil;

prairie vegetation rain garden in sand soil;

all rooftop area tributary to corresponding LID;

historical precipitation measured at each LID location; and

- historical evapotranspiration values for Madison

The model was created with four impervious catchments to represent the rooftops. Four LID controls were established in the model to represent the rain gardens in the Madison study. Characteristics of each LID control were established from measured values or acceptable published values where measured values were not available. Similar parameters were used for each bioretention LID control. Principal differences among the LID controls were the percentage of vegetative cover between the turfgrass and the prairie grass rain gardens, and the porosity of the soil between the clay and sand rain gardens.

The model was used to simulate 2004 through 2007. The results indicate that the model can be calibrated to match the long term values reported in the Madison study. Results from the observed data and modeled data are discussed in detail in Section 15.2. In addition to long term calibration and verification, the model was used to simulate a single event reported in detail by the Madison study.

\subsection{Results and Discussions}

\subsubsection{Long Term Simulation Results}

Long term simulation was performed using the model for 2004 through 2007. Model results match the observed field data well. 
The observations indicate that the turf-sand rain garden received 647 in. (1 $643 \mathrm{~cm}$ ) influent and discharged no effluent during the $4 \mathrm{y}$ study period. Altogether, $85 \%$ of the influent exited the rain garden as infiltration while the remainder left as evapotranspiration.

The model simulated 3 in. $(5.1 \mathrm{~cm})$ effluent for the turf-sand bioretention control. Modeled recharge as a percentage of total influent (91\%), and reported recharge $(85 \%)$ both match within the acceptable range of error associated with field measurements. The model simulated higher total influent to the turf-sand rain garden than was measured. While measured precipitation data was used as input to the model, the slope of the tributary area was estimated for the model based on local building codes for minimum slope. This could account for the larger amounts of runon simulated by the model than reported from the field.

The reported field data indicates that the prairie-sand rain garden experienced approximately $611 \mathrm{in.}(1552 \mathrm{~cm})$ influent and no effluent over the 4 y period. Evapotranspiration accounted for $10.5 \%$ losses, while infiltration accounted for the balance of the water.

The model simulated 2 in. $(5.1 \mathrm{~cm})$ effluent for the prarie-sand bioretention control. As a percentage of total influent, model recharge (90\%) and reported recharge (88-91\%) both match within the acceptable range of error associated with field measurements. The modeled data reported higher total influent to the prairie-sand rain garden than the measured data. While the measured precipitation data was used in the input to the model, the slope of the catchment tributary to the LID was not reported and was assumed based on local building codes for minimum slope. This could be an explanation for the larger amounts of runon predicted by the model than reported from the field. Table 15.1 summarizes the long term reported data and simulation results for both the turf-sand and prairie-sand rain gardens.

Table 15.1 Results for sand rain gardens 2004 through 2007.

\begin{tabular}{lcccc}
\hline \multirow{2}{*}{ Constituent } & \multicolumn{2}{c}{ Turf } & \multicolumn{2}{c}{ Prairie } \\
\cline { 2 - 5 } & $\begin{array}{c}\text { Measured } \\
\text { (inches) }\end{array}$ & $\begin{array}{c}\text { Simulated } \\
\text { (inches) }\end{array}$ & $\begin{array}{c}\text { Measured } \\
\text { (inches) }\end{array}$ & $\begin{array}{c}\text { Simulated } \\
\text { (inches) }\end{array}$ \\
\hline Precipitation & 147 & 137 & 147 & 137 \\
Run-on & 500 & 691 & 464 & 691 \\
Total Influent & 647 & 828 & 611 & 828 \\
Effluent & $0(0 \%)$ & $2(0 \%)$ & $0(0 \%)$ & $1(0 \%)$ \\
Evapotranspiration & $96(15 \%)$ & $84(10 \%)$ & $51-70(9 \%-12 \%)$ & $91(11 \%)$ \\
Recharge & $550(85 \%)$ & $749(91 \%)$ & $540-560$ & $745(90 \%)$ \\
\hline
\end{tabular}


The field data indicate that the turf-clay rain garden received $748 \mathrm{in}$. (1 $900 \mathrm{~cm})$ influent during the 4 y study. For this same period, 8 in. $(20.3 \mathrm{~cm})$ effluent were observed. Altogether $85 \%$ of the turf-clay influent exited the rain garden as infiltration while the remainder left as evapotranspiration.

The model simulated $10 \mathrm{in}$. $(25.4 \mathrm{~cm})$ effluent for the turf-clay bioretention LID control. Modeled recharge (86\%) and reported recharge $(85 \%)$ as a fraction of total influent are within the acceptable range of error associated with field measurements. The measurements indicate higher total influent to the prairie-clay rain garden than was simulated. While measured precipitation was input to the model, the roof slope of the catchment tributary to the LID was simulated as flat. The model may use a flatter slope than actual field conditions. This could explain the larger observed runon than was simulated by the model.

The field data indicates that the prairie-clay rain garden experienced approximately 706 in. $(1793 \mathrm{~cm})$ influent during the 4 y period of interest. For this same time period, 0 in. $(0 \mathrm{~cm})$ effluent was observed. Approximately $6 \%$ of the prairie-clay influent exited the rain garden as evapotranspiration while the remainder left as infiltration.

Effluent simulated by the model was $1 \mathrm{in}$. $(2.54 \mathrm{~cm})$ for the prairie-clay bioretention LID control. As a fraction of total influent, modeled (92\%) and reported recharge (91.75\% to $96.75 \%$ ) both lie within the acceptable range of error associated with field measurements. The measurements indicate higher total influent to the prairie-clay rain garden than was simulated by the model. While measured precipitation data was input to the model, the roof slope of the tributary area was assumed to be flat. The modeled slope may have been too low. This could explain the larger observed runon reported from the field than simulated by the model. Table 15.2 summarizes the long term field data and simulation results for both the turf-clay and prairie-clay rain gardens.

Table 15.2 Results for clay rain gardens 2004 through 2007.

\begin{tabular}{lcccc}
\hline \multirow{2}{*}{ Constituent } & \multicolumn{2}{c}{ Turf } & \multicolumn{2}{c}{ Prairie } \\
\cline { 2 - 5 } & $\begin{array}{c}\text { Measured } \\
\text { (inches) }\end{array}$ & $\begin{array}{c}\text { Simulated } \\
\text { (inches) }\end{array}$ & $\begin{array}{c}\text { Measured } \\
\text { (inches) }\end{array}$ & $\begin{array}{c}\text { Simulated } \\
\text { (inches) }\end{array}$ \\
\hline Precipitation & 145 & 140 & 145 & 140 \\
Run-on & 603 & 566 & 485 & 497 \\
Total Influent & 748 & 706 & 630 & 507 \\
Effluent & $8(1 \%)$ & $10(1 \%)$ & $0(0 \%)$ & $1(0 \%)$ \\
Evapotranspiration & $93(12 \%)$ & $87(12 \%)$ & $19-47(3 \%-7.5 \%)$ & $55(9 \%)$ \\
Recharge & $637(85 \%)$ & $611(86 \%)$ & $584-613$ & $584(92 \%)$ \\
\hline
\end{tabular}


While field data were used as model input wherever practical, several values for LID control parameters and the general model setup required assumptions. These assumptions may influence the results and account for differences between the measurements and simulated results. Performing a sensitivity analysis on the slope of the catchment tributary to the LID as well as other assumed parameters was not part of this study. A sensitivity analysis would provide additional insight; however, for both the clay and sand rain gardens, the error between the reported effluent volumes from the LIDs, is $0 \%$ and the maximum error between the evapotranspiration and recharge is $5 \%$.

The key calibration focus was the effluent volume from the LID and the split between the ET and recharge volumes. Other internal LID performance indicators were not the focus of this effort. These differences between the model results and the observed data at the key calibration points are well within acceptable ranges for modelling error; no sensitivity analyses were performed on the estimated parameters.

\subsubsection{Single Event Simulation Results}

A storm on 20040523 was used to illustrate that the model can be calibrated for single events. The values of the LID control parameters were not the same for the single event calibration as for the long term calibration. While individual parameters were adjusted to calibrate to a single event rather than long term data, the values of each parameter were well within the acceptable published ranges for each parameter.

Several possible explanations may explain why the model parameters vary from long term to short term calibration. First, antecedent moisture conditions influence the LID's infiltration capacity. Second, the parameters for porosity and saturated hydraulic conductivity are generally lower for the long term calibration than for the short term to compensate for clogging, debris and suchlike.

Comparison of observed and modeled results for the 20040523 event indicates that the model can be calibrated to match short term field observations. Observations are shown in Figure 15.5. Model results are presented in Figure 15.6 overleaf.

The first and second major peaks align closely between the measurements and model results. The principal difference is the volume under the curve. The falling limb of the model depth does not drop as quickly as the field data. Additional model runs to address this issue did not improve the results. While this is not a critical issue for single event simulation, it could adversely influence the performance of long term simulations. 


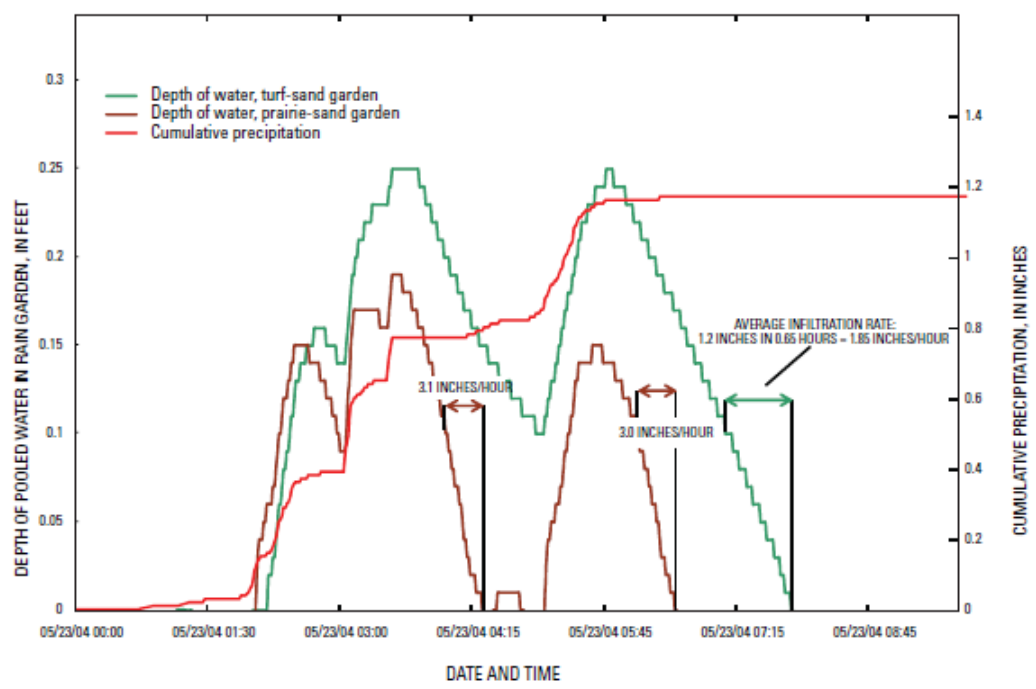

Figure 15.5 Results from Madison, Wisconsin field data for single event (used with permission from Selbig and Balster, 2010).

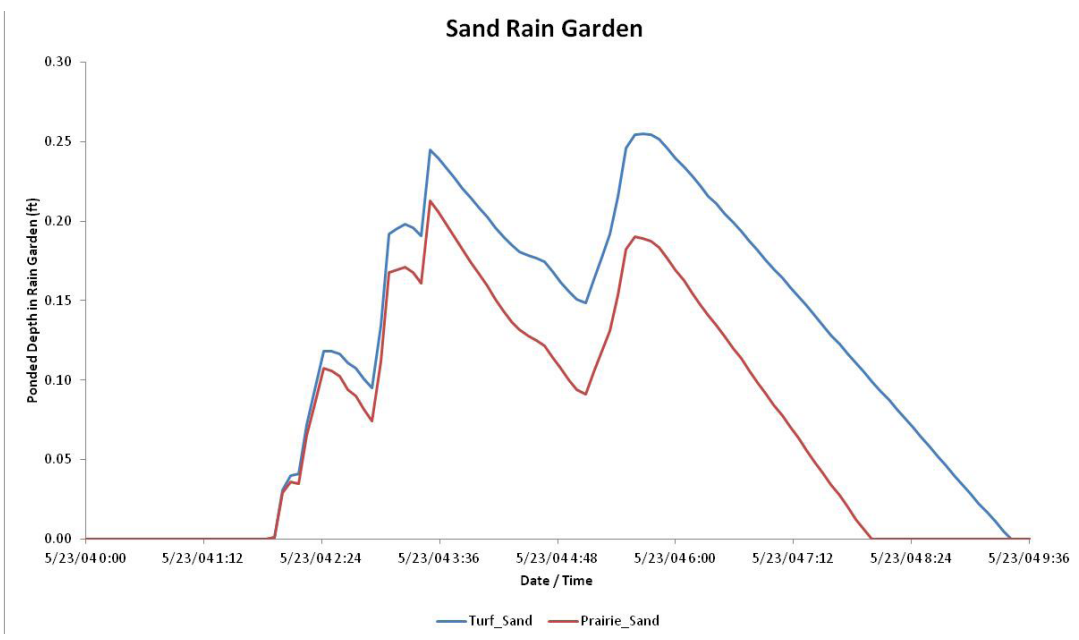

Figure 15.6 Simulated single event ponded depth.

\subsection{Findings and Observations}

LID controls are an important addition to SWMM, given the increasing interest in use of green infrastructure to reduce urban runoff. Many public and 
private entities are considering green infrastructure in future developments or as remediation techniques for stormwater problems. The application of green infrastructure and LID continues to grow worldwide. SWMM's LID controls are a useful tool for analyzing the impacts of green infrastructure on stormwater and sanitary collection systems. Proper implementation and representation of green infrastructure in SWMM is critical to generating reliable results.

The model simulations presented in this study represent one application of green infrastructure. The field measured data provided a benchmark for the expected model results. Other applications of green infrastructure include, but are not limited to, new residential development, new commercial development, retrofitting older neighborhoods with existing stormwater infrastructure, and combined sewer separation.

Overall, the bioretention cell LID control was found to replicate published results reasonably well for single event and long term simulation. This study shows that the model can be calibrated against measured results. A similar study (McCutcheon et al., 2012) was unable to confirm the validity of the SWMM LID controls because of a lack of field data for comparison. The difference between this study and McCutcheon et al. (2012) is the use of measured field data as part of the model input. Use of field data made a significant difference in model performance. The good performance of the bioretention cell, and its similarity with algorithms for other LID controls, suggest that the LID controls perform well in SWMM version 5.0.022.

The study found differences between best fit LID parameters for single event and long term parameters. This is acceptable when the intended end use of the model differs.

The study also identified differences between field observations and model results. Measured field data lead to greater credibility and confidence in the model; however, inherent uncertainty exists in all field measurements. Where field data were unavailable, this study relied on acceptable published values which vary widely across different published references. Sound engineering judgment is still necessary to interpret model inputs and results. Modelling is a tool, not a replacement for sound engineering judgment; however, a model with a strong physical basis offers greater potential accuracy. Although it was outside the scope of this project, a sensitivity analysis of the parameters that are not field measured could help clarify the reported results.

This study recommends several action items that can strengthen the confidence in utilizing the SWMM 5 LID Controls as well as potentially enhancing them.

1. Long term monitoring of green infrastructure and LID devices is most required if they are to be represented accurately in mod- 
els. While many entities are constructing LIDs, post-construction monitoring is often neglected.

2. A national or international database of performance data could be created for engineering reference. LID performance varies with geography. A database could contain detailed regional specific seasonal (growth and dormant) soil parameters required for LID modeling. This process has already been started by the International Stormwater BMP Database project team. Team members and sponsors currently include the Water Environment Research Foundation as the lead sponsor and the American Society of Civil Engineers Environmental Water Resources Institute, the American Public Works Association, the USEPA, and the Federal Highway Administration as cosponsors.

3. Validating all SWMM5 LID controls with a robust set of reliable field data for both input parameters and model calibration performance from a variety of LID sites representing various field conditions.

4. Explore differences in calibrations by performing detailed sensitivity analyses to help determine whether mathematical changes in the software code would be warranted.

As better monitoring data is collected and shared within the engineering community, better models can be developed. As the engineering community enhances its models, it will also build understanding of the model representation of the physical processes of green infrastructure. Reliable collection systems models depend on reliable flow monitoring data. Reliable LID modelling will be established on reliable field data as well.

\section{References}

Akan, A. O. Modified Rational Method for Sizing Infiltration Structures. Canadian Journal of Civil Engineering, Vol. 29, No. 4, August 2002.

Gironas, J., L. A. Roesner and J. Davis. Stormwater Management Model Applications Manual. EPA/600/R-09/000 U.S. Environmental Protection Agency, National Risk Management Research Laboratory, Cincinnati, OH. July 2009. www.epa.gov/nrmrl/ wswrd/wq/models/swmm

Heitz, L. F., S. Khosrowpanah and J. Nelson. Sizing of Surface Water Runoff Detention Ponds for Water Quality Improvement. Journal of the American Water Resources Association, Vol. 36, Issue 3, June 2000.

International Stormwater BMP Database. www.bmpdatabase.org, 2012. 
McCutcheon, M. D., D. D. Wride and J. A. Reinicke. 2012. An Evaluation of Modeling Green Infrastructure Using LID Controls. Journal of Water Management Modeling R245-12. doi: 10.14796/JWMM.R245-12.

Mungasavalli, D. P. and T. Viraraghavan. Constructed Wetlands for Stormwater Management: A Review. Fresenius Environmental Bulletin, Vol. 15, No. 11, November 2006.

Selbig, W.R. and N. Balster. Evaluation of Turf-Grass and Prairie-Vegetated Rain Gardens in a Clay and Sand Soil, Madison, Wisconsin, Water Years 2004-08: U.S. Geological Survey Scientific Investigations Report 2010-5077, 72p, 2010. 
